Research Article

\title{
Genotoxicity of Nicotiana tabacum leaves on Helix aspersa
}

Fernanda R. da Silva ${ }^{1}$, Bernardo Erdtmann ${ }^{1}$, Tiago Dalpiaz ${ }^{2}$, Emilene Nunes ${ }^{2}$, Alexandre Ferraz ${ }^{2}$, Tales L.C. Martins ${ }^{3}$, Johny F. Dias ${ }^{4}$, Darlan P. da Rosa ${ }^{5}$, Marilene Porawskie ${ }^{5,6}$, Silvia Bona ${ }^{5}$ and Juliana da Silva ${ }^{2}$

${ }^{1}$ Programa de Pós-Graduação em Genética e Biologia Molecular, Universidade Federal do Rio Grande do Sul, Porto Alegre, RS, Brazil.

${ }^{2}$ Laboratory of Genetic Toxicology, Programa de Pós-graduação em Biologia Molecular e Celular Aplicada à Saúde, Universidade Luterana do Brasil, Canoas, RS, Brazil.

${ }^{3}$ Universidade Federal do Pampa, Campus Bagé, Bagé, RS, Brazil.

${ }^{4}$ School of Physics, Universidade Federal do Rio Grande do Sul, Porto Alegre, RS, Brazil.

${ }^{5}$ Laboratory of Experimental Hepatology, Teaching Hospital of Porto Alegre, Porto Alegre, RS, Brazil.

${ }^{6}$ Faculty of Biosciences, Pontificial Catholic University of Rio Grande do Sul, Porto Alegre, RS, Brazil.

\begin{abstract}
Tobacco farmers are routinely exposed to complex mixtures of inorganic and organic chemicals present in tobacco leaves. In this study, we examined the genotoxicity of tobacco leaves in the snail Helix aspersa as a measure of the risk to human health. DNA damage was evaluated using the micronucleus test and the Comet assay and the concentration of cytochrome P450 enzymes was estimated. Two groups of snails were studied: one fed on tobacco leaves and one fed on lettuce (Lactuca sativa $L$ ) leaves (control group). All of the snails received leaves (tobacco and lettuce leaves were the only food provided) and water ad libitum. Hemolymph cells were collected after $0,24,48$ and $72 \mathrm{~h}$. The Comet assay and micronucleus test showed that exposure to tobacco leaves for different periods of time caused significant DNA damage. Inhibition of cytochrome P450 enzymes occurred only in the tobacco group. Chemical analysis indicated the presence of the alkaloid nicotine, coumarins, saponins, flavonoids and various metals. These results show that tobacco leaves are genotoxic in $H$. aspersa and inhibit cytochrome P450 activity, probably through the action of the complex chemical mixture present in the plant.
\end{abstract}

Keywords: comet assay, genotoxicity, micronucleus test, Helix aspersa, Nicotiana tabacum, tobacco leaves.

Received: November 30, 2012; Accepted: March 12, 2013.

\section{Introduction}

Brazil is the world's second largest producer of tobacco (Nicotiana tabacum) leaves after China and accounts for $14.1 \%$ of the global production. The southern Brazilian state of Rio Grande do Sul (RS) is the largest tobacco producer in the country. More than 320,000 tons are produced annually, with over 906,000 workers employed in direct farming and 40,000 jobs in cigarette factories (AFUBRA, 2012).

Tobacco farmers are routinely exposed to the complex mixture of chemicals present in tobacco leaves, in addition to organic and inorganic pesticides used to treat tobacco plants. Tobacco leaves contain an unusually high number of different chemical compounds, such as nicotine,

Send correspondence to Juliana da Silva. Programa de PósGraduação em Biologia Molecular e Celular Aplicada à Saúde, Universidade Luterana do Brasil, Av. Farroupilha 8001, Prédio 22, Quarto andar, 92425-900 Canoas, RS, Brazil. E-mail: juliana.silva@ulbra.br. nicotianine and malic acid (Hinds, 2012). These farmers are at risk of Green Tobacco Sickness (GTS), a disease caused by the dermal absorption of nicotine from wet tobacco leaves. The signs and symptoms of GTS include nausea, pallor, chills, vomiting, headache, difficulty in breathing, abdominal pain, diarrhea, loss of appetite, runny eyes, blurred vision, weakness, prostration and dizziness, and, occasionally, fluctuations in blood pressure or heart rate (Onuki et al., 2003; Parikh et al., 2005).

Nicotine is the most important alkaloid present in tobacco. The quantity of nicotine in dried tobacco leaves varies from $4 \%$ to $8 \%$ (Hinds, 2012; IPCS-INCHEM, 2012). During harvest time, farm workers may be exposed to up to $600 \mathrm{~mL}$ of dew or rain on the tobacco plants, which roughly corresponds to the nicotine content of 36 cigarettes (NIOSH, 2012). There have been few studies on the genotoxicity of nicotine and the findings are contradictory. Some authors have reported that nicotine and its four major metabolites are not genotoxic when assayed in the Ames 
test or other bacterial indicator assays (Doolittle et al., 1995), whereas others have observed that tobacco induces DNA alterations in mammalian cells (Munzner and Renner, 1989; Trivedi et al., 1990).

In contrast to other techniques, the study of bioindicator organisms can reveal the biologic impact of xenobiotics. Among terrestrial invertebrates, the snail $\mathrm{He}$ lix aspersa can accumulate different classes of chemicals and therefore serve as a pertinent species for monitoring trace metals and agrochemicals (Snyman et al., 2000; Beeby and Richmond, 2002) as well as plant extracts (Pereira et al., 2009). Xenobiotics accumulated through different routes are transported by blood cells to the digestive gland, which is also the main target organ for metabolic and detoxification processes (Beeby and Richmond, 2002).

In this study, we adapted the micronucleus test to investigate the response of $H$. aspersa to exposure to tobacco leaves as an indicator of the risk to human health. DNA damage was assessed with the micronucleus test (MN) and the Comet assay in hemolymph cells, and the inhibition of cytochrome P450 enzyme activity was also examined. In addition, trace element analysis, phytochemical screening and nicotine quantification were also done.

\section{Materials and Methods}

\section{Plant material}

Nicotiana tabacum leaves were collected on a farm in the south-central region of Rio Grande do Sul State, Brazil. Only tobacco leaves without pesticides were sampled. The leaves were packed and stored in a freezer at $-30{ }^{\circ} \mathrm{C}$.

\section{Snails}

Adult individuals $(\mathrm{n}=20)$ of the land snail H. aspersa $(8.96+1.62 \mathrm{~g}$; mean $+\mathrm{SD})$ were obtained from a snail breeder at the Lutheran University of Brazil, Canoas, RS, Brazil. The snails were acclimatized in a cage at $22+3{ }^{\circ} \mathrm{C}$ for seven days, during which period they received leaves from organically grown lettuce (Lactuca sativa L.) and water ad libitum. After acclimatization, the snails were assigned to control and test groups.

\section{Treatments and hemolymph sampling}

The study involved two groups of snails: the first was fed tobacco leaves and the second was fed lettuce leaves (control group) ( $\mathrm{n}=10 \mathrm{each})$. All snails received tobacco or lettuce leaves (the only food provided) and water ad libitum. Hemolymph samples for the Comet assay were obtained from the snails $0 \mathrm{~h}, 24 \mathrm{~h}, 48 \mathrm{~h}$ and $72 \mathrm{~h}$ after the beginning of feeding each type of leaf, and after $72 \mathrm{~h}$ for the micronucleus test. The snails were weighed every day throughout the experiment. The hemolymph samples were collected using a syringe containing heparin and processed within $30 \mathrm{~min}$ of collection. At the end of the $72 \mathrm{~h}$ period, all snails were killed and stored in a freezer at $-30{ }^{\circ} \mathrm{C}$ for trace element analysis and determination of cytochrome P450 activity.

\section{Comet assay}

The alkaline Comet assay was done as described by Singh et al. (1998) with several modifications for hemolymph (Ianistcki et al., 2009). Images of 100 randomly selected cells (50 cells from each of two replicate slides) were analyzed for each individual. To calculate a damage index (DI), cells were visually classified into one of five classes based on tail size $(0=$ no tails and $4=$ maximum-length tails) as assessed by light microscopy. This classification resulted in a single DNA damage score for each individual and consequently for each group studied. The DI for each individual could range from 0 (completely undamaged $=100$ cells $\times 0$ ) to 400 (maximum damage $=$ 100 cells $x 4$ ). The damage frequency (DF, in \%) was calculated for each sample based on the number of cells with tails vs. those without tails (Heuser et al., 2002). All sides were coded for blind analysis.

\section{Micronucleus test (MN)}

The MN test was done on hemolymph as a second monitoring system for comparison with the alkaline Comet assay. The MN test was adapted to the characteristics of the test organism based on a protocol described for Limnoperna fortunei, a mussel species (Villela et al., 2007). A syringe containing $0.5 \mathrm{~mL}$ of freshly prepared methanol:acetic acid $(1: 1, \mathrm{v} / \mathrm{v})$ was used to collect the same volume $(0.5 \mathrm{~mL})$ of hemolymph. The syringe was briefly placed on ice (7-10 $\mathrm{min}$ ) and the hemolymph samples then smeared onto microscope slides, fixed in methanol for 10 min, air-dried and stained for $7 \mathrm{~min}$ with a mixture of 10 $\mathrm{mL}$ Giemsa and $90 \mathrm{~mL} 0.2 \mathrm{M}$ phosphate buffer (pH 5.8) prior to examination by light microscopy. Two thousand cells in two hemolymph smears from each snail were examined for the presence or absence of micronuclei. All sides were coded for blind analysis.

\section{Enzyme analysis}

For microsome preparation the tissue (digestive gland) was homogenized in an Ultra-Turrax homogenizer for $15 \mathrm{~s}$ in a tissue:buffer $(0.1 \mathrm{M}$ potassium phosphate, $\mathrm{pH}$ $7.5, \quad 0.15 \mathrm{M} \mathrm{KCl}, 10 \mathrm{mM}$ EDTA and $0.1 \mathrm{mM}$ phenylmethylsufonyl fluoride) ratio of 1:5 (w/v). The homogenate was centrifuged at $12,000 \mathrm{x} g$ for $20 \mathrm{~min}$ and the supernatant then centrifuged twice at 105,000 x $g(60 \mathrm{~min}$ each). The resulting microsome fraction was resuspended in buffer $(0.2 \mathrm{M}$ potassium phosphate, $\mathrm{pH} 7.5,0.15 \mathrm{M} \mathrm{KCl}$, $10 \mathrm{mM}$ EDTA, $0.1 \mathrm{mM}$ phenylmethylsufonyl fluoride and $20 \%$ glycerol) at a tissue:buffer ratio of 1:3 and then stored at $-70{ }^{\circ} \mathrm{C}$ (Vrolijk et al., 1994).

The microsomal protein concentrations (expressed in $\mathrm{mg} / \mathrm{mL}$ ) were determined as described by Lowry et al. (1951) using bovine serum albumin as the standard. The 
samples were assayed in duplicate and the final absorbance was read at $625 \mathrm{~nm}$ in a spectrophotometer.

For the spectral characterization of cytochrome $b_{5}$, P450 and P420: the microsomal suspension was diluted to $1 \mathrm{mg} / \mathrm{mL}$ and sodium dithionite crystals were added for analysis of cytochrome $b_{5}$. The samples were read against a suspension of microsomes. Cytochromes P450 and P420 were identified based on the compound formed by the interaction of reduced microsomes with sodium dithionite and $80 \mu \mathrm{L}$ of carbon monoxide. This mixture was analyzed against a microsomal suspension reduced with sodium dithionite (Omura and Sato, 1964). The measurements were done in a Beckman DU70 spectrophotometer at $400-700 \mathrm{~nm}$.

\section{Chemical analysis of tobacco leaves}

Tobacco leaves were oven-dried for $4 \mathrm{~h}$ at $60{ }^{\circ} \mathrm{C}$ and then were ground to a fine powder. The tobacco leaf powder was used to prepare pellets for trace element analysis using the PIXE (Particle-Induced X-ray Emission) technique and phytochemical screening. Nicotine was quantified by HLPC.

For the PIXE analysis, the pellets were placed in the target holder inside the reaction chamber. During the experiments, the pressure inside the reaction chamber was $\sim 10^{-5}$ mbar. The experiments were carried out at the Ion Implantation Laboratory of the Institute of Physics, Federal University of Rio Grande do Sul (IF-UFRGS). A 3 MV Tandetron accelerator provided a $2 \mathrm{MeV}$ proton beam with an average current of $5 \mathrm{nA}$ at the target. The X-rays produced in the samples were detected by a germanium $(\mathrm{Ge})$ detector with an energy resolution of about $180 \mathrm{eV}$ in $5.9 \mathrm{keV}$ with high efficiency between 3 and $100 \mathrm{keV}$. The spectra were analyzed with the GUPIX software package and the amounts were expressed in ppm (Campbell et al., 2000).

The phytochemical profile of $N$. tabacum leaves was determined as described by Harborne (1998). The method consists of several procedures for the detection of flavonoids, tannins, anthraquinones, alkaloids, saponins, coumarins and cardiac glycosides. The confirmatory thin layer chromatography analysis was done using the systems and developers indicated by Wagner and Bladt (1996).

The nicotine dosage in tobacco leaves extracted with water was determined by HPLC. Standard nicotine was purchased from Sigma (lot no. 093K4121). Analysis was done on a C18 reverse-phase column (cartridge: $5 \mu \mathrm{m}$, $250 \times 4.6 \mathrm{~mm})$. The separation was done at $35^{\circ} \mathrm{C}$. The isocratic mobile phase used was a mixture of aqueous phase (phosphate buffer, $\mathrm{pH} \mathrm{6.8,} \mathrm{and} \mathrm{methanol} \mathrm{at} \mathrm{a} \mathrm{ratio} \mathrm{of} \mathrm{35:65,}$ $\mathrm{v} / \mathrm{v})$. The solution was sonicated before use and the flow rate was $1.2 \mathrm{~mL} / \mathrm{min}$. The HPLC method used was based on work by Tambwekar et al. (2003). A stock solution of nicotine $(1 \mathrm{mg} / \mathrm{mL})$ was prepared by dissolving $100 \mathrm{mg}$ in $100 \mathrm{~mL}$ of phosphate buffer ( $\mathrm{pH}$ 6.8). Various dilutions
(2.5-50 $\mu \mathrm{g} / \mathrm{mL}$; five points per curve) were prepared the areas under the peaks were determined for each concentration (assayed in quadruplicate) and used to construct the standard curve. The retention time of nicotine was $\sim 3.93 \mathrm{~min}$. The assay was linear within the expected concentration range, indicating its suitability for this analysis. The equation of the regression curve was $y=0.02475+0.00005 x$ and $\mathrm{r}^{2}$ was 0.996 . Tobacco leaves $(65 \mathrm{~g})$ were washed with $70 \mathrm{~mL}$ of distilled water and the resulting solution was lyophilized and yielded $705 \mathrm{mg}$ of residue. The crude extract (100 mg; labeled as solution A) was dissolved in $100 \mathrm{~mL}$ of phosphate buffer (pH 6.8) and a $20 \mu \mathrm{L}$ aliquot was injected (in triplicate) and eluted with the mobile phase (10 mM phosphate buffer ( $\mathrm{pH} 6.8)$ :methanol, 35:65 v/v). No interfering substances were detected in the chromatogram.

\section{Statistical analysis}

The normality of the data was evaluated using the Kolmogorov-Smirnov test. Statistical comparisons between the groups were done using Student's two-tailed $t$-test. Differences between exposure times were analyzed using the non-parametric two-tailed Kruskal-Wallis test followed by Dunns test for multiple comparisons. The critical level for rejection of the null hypothesis was $p<0.05$.

\section{Results}

Table 1 summarizes the Comet assay data expressed as Damage index and Damage frequency for $H$. aspersa hemolymph cells exposed to tobacco leaves compared to cells from control snails. Control snails (fed lettuce leaves) showed no significant variation throughout the experiment, although there was a slight increase in DNA damage after $48 \mathrm{~h}$ and $72 \mathrm{~h}$. There was also no difference between the groups (control and tobacco leaves) at $0 \mathrm{~h}$. However, snails fed tobacco leaves had higher values than the control group at all subsequent times. When analyzed by the KruskalWallis test, the mean DI and DF for snail hemolymph cells after 24,48 and $72 \mathrm{~h}$ of exposure were significantly higher than those of the corresponding controls and the values at $0 \mathrm{~h}$ (see Table 1 for $\mathrm{p}$ values).

Figure 1 shows the micronucleus test (MN) results for hemolymph cells after $72 \mathrm{~h}$. Cells from snails fed tobacco leaves had a significantly higher MN value than the control group (Student's $t$-test). Signs of toxicity such as swelling and death were observed in some snails at the end of the $72 \mathrm{~h}$ treatment period.

Table 2 shows that 11 trace elements were detected in the tobacco leaf samples analyzed using PIXE. There was no significant difference in the protein content of the digestive glands of snails in the two groups, but there was a significant reduction in the cytochrome $\mathrm{b}_{5}, \mathrm{P} 450$ and P420 activities in snails fed tobacco leaves (Table 3). 
Table 1 - Damage index and damage frequency (Comet assay) in hemolymph of snails exposed to tobacco leaves or lettuce leaves (control group).

\begin{tabular}{lccccc}
\hline \multirow{2}{*}{ Exposure time $(\mathrm{h})$} & \multicolumn{4}{c}{ Exposure group } \\
\cline { 2 - 3 } \cline { 5 - 6 } \cline { 5 - 6 } & \multicolumn{2}{c}{ Control } & & \multicolumn{2}{c}{ Tobacco leaves } \\
\hline 0 & $56.80+34.53$ & $29.90+14.16$ & & $60.00+22.98$ & $29.00+10.88$ \\
24 & $53.60+36.76$ & $28.30+17.34$ & & $166.80+45.29^{* *, a}$ & $73.90+14.22^{* *, a}$ \\
48 & $96.60+41.18$ & $44.50+18.11$ & & $207.60+48.52^{* *,}$ a & $83.00+16.05^{* *, a}$ \\
72 & $97.50+38.55$ & $45.60+17.78$ & & $224.10+42.95^{* * *, a}$ & $88.40+7.32^{* * *, a}$ \\
\hline
\end{tabular}

The values are the mean $+\mathrm{SD}$ of 10 snails per group. ${ }^{* *} \mathrm{p}<0.01$ and ${ }^{*} \mathrm{p}<0.001$ compared to the corresponding control parameter (Students $t$-test). ${ }^{\mathrm{a}} \mathrm{p}<0.05(24 \mathrm{~h}$ ) and $\mathrm{p}<0.001$ (48 h and $72 \mathrm{~h}$ ) compared to $0 \mathrm{~h}$ (Kruskal-Wallis test).

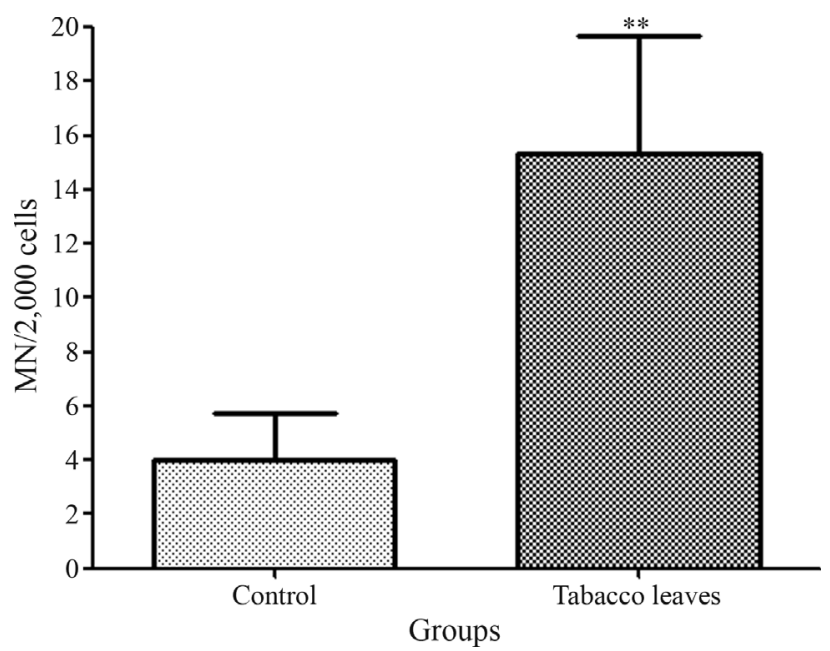

Figure 1 - Detection of micronuclei (MN) in hemolymph cells of Helix aspersa exposed to tobacco leaves. The columns represent the mean $+\mathrm{SD}$ determined in 10 snails of each group. ${ }^{*} \mathrm{p}<0.01$ compared to snails fed lettuce leaves (control) (Students $t$-test).

The nicotine concentration in the extract was $22.36 \mu \mathrm{g} / \mathrm{mL}$ (solution A). The solution obtained from washed tobacco leaves was lyophilized and yielded $705 \mathrm{mg}$ of residue. Extraction of $65 \mathrm{~g}$ of this residue with $70 \mathrm{~mL}$ of water yielded $15.76 \mathrm{mg}$ of nicotine, which corresponded to $\sim 0.02 \%$ of nicotine per leaf. Phytochemical analysis of tobacco leaves revealed the presence of coumarins, saponins traces, alkaloids and flavonoids.

\section{Discussion}

Substances present in tobacco form a complex mixture of organic and inorganic compounds that may interact to produce additive, synergistic or antagonistic effects (Fent, 2003). In the present study, the results of the Comet assay and MN test (Table 1 and Figure 1) of hemolymph from snails (H. aspersa) fed tobacco leaves were significantly higher than those of the control group (fed lettuce). The application of the Comet assay in these snails has been shown to be an inexpensive, effective and sensitive method for assessing the genotoxicity of chemical mixtures
Table 2 - Content of trace elements (ppm) in tobacco leaves.

\begin{tabular}{lcc}
\hline Trace element & Tobacco leaves & Lettuce leaves $^{\mathrm{a}}$ \\
\hline $\mathrm{Na}$ & $458965+38828$ & 995.70 \\
$\mathrm{~K}$ & $33449+508$ & 0.11 \\
$\mathrm{Mg}$ & $4138+224$ & 15.31 \\
$\mathrm{P}$ & $1659+94$ & 0.03 \\
$\mathrm{~S}$ & $1822+75$ & 0.01 \\
$\mathrm{Cl}$ & $3425+112$ & 0.01 \\
$\mathrm{Al}$ & $1272+342$ & 0.90 \\
$\mathrm{Si}$ & $1470+90$ & 1.95 \\
$\mathrm{Ti}$ & $140+10$ & $2.47 \times 10^{-4}$ \\
$\mathrm{Ca}$ & $\mathrm{ND}$ & 0.07 \\
$\mathrm{Fe}$ & $\mathrm{ND}$ & $1.32 \times 10^{-3}$ \\
$\mathrm{Cu}$ & $\mathrm{ND}$ & $7.25 \times 10^{-5}$ \\
$\mathrm{Mn}$ & $85+5$ & $4.60 \times 10^{-5}$ \\
$\mathrm{Zn}$ & $31+4$ & $1.35 \times 10^{-4}$ \\
\hline
\end{tabular}

Values are the mean $+\mathrm{SD}$ of 3 determinations. ${ }^{\mathrm{a}}$ Data from Leffa et al. (2010). ND = not detected (samples with content below the limit of detection). Limits of detection: $\mathrm{Ca}=2.60 \times 10^{-3}, \mathrm{Cu}=4.03 \times 10^{-5}$ and $\mathrm{Fe}=1.02 \times 10^{-4}$.

(Ianistcki et al., 2009). The Comet assay detects recent lesions that can be repaired, such as breaks and alkali-labile sites, while the MN test detects non-repairable damage, such as clastogenic and aneugenic lesions (Villela et al., 2007). Our findings show that the compounds present in tobacco leaves were genotoxic and mutagenic in $H$. aspersa. The slight time-dependent increase in DNA damage (seen in the Comet assay) in untreated snails can be explained by animal stress. Other reports have described similar results for controls (Villela et al., 2007). Since the frequency of $\mathrm{MN}$ seen here in the control group was within an acceptable range, our results can be considered reliable.

The phytochemical analysis revealed the presence of alkaloids in tobacco leaves. Hinds (2012) stated that nicotine is the main tobacco alkaloid. Using HPLC, we found a nicotine content of $\sim 0.02 \%$ per leaf. This lower value of nicotine compared to that reported by others (IPCS- 
Table 3 - Protein content and cytochrome activities of digestive glands from Helix aspersa individuals exposed to lettuce leaves (control) or tobacco leaves.

\begin{tabular}{lcc}
\hline Parameters & Control $(\mathrm{n}=6)$ & Tobacco leaves $(\mathrm{n}=6)$ \\
\hline Protein $(\mathrm{mg} / \mathrm{mL})$ & $8.33+0.49$ & $6.59+2.23$ \\
Cytochrome $b_{5}(\mathrm{nmol} / \mathrm{mg})$ & $35.47+4.26$ & $26.92+2.86^{* *}$ \\
Cytochrome P450 $(\mathrm{nmol} / \mathrm{mg})$ & $126.09+6.99$ & $84.6+15.48^{* * *}$ \\
Cytochrome P420 $(\mathrm{nmol} / \mathrm{mg})$ & $231.72+12.41$ & $149.55+31.98^{* * *}$ \\
\hline
\end{tabular}

The values are the mean $+\mathrm{SD} .{ }^{*} \mathrm{p}<0.01$ and ${ }^{*} \mathrm{p}<0.001$ compared to the control group (Students $t$-test).

INCHEM, 2012) can be explained by the extraction method used. The highest frequency of damage was observed after $72 \mathrm{~h}$, although a similar extent of damage was observed after $24 \mathrm{~h}$. Argentin and Cichetti (2004) applied the MN test to cultured mammalian cells treated with nicotine and observed rapid induction of DNA damage in samples treated for up to $72 \mathrm{~h}$, with maximum levels observed after $24 \mathrm{~h}$ of exposure. Nicotine caused a concentration-dependent increase in DNA fragmentation, as assessed by the Comet assay, in mini-organ cultures of human nasal epithelium, indicating a direct genotoxic effect (Sassen et al., 2005); similar findings have been reported for lymphatic tissue of palatine tonsils and peripheral lymphocytes (Kleinsasser et $a l .$, 2005). Nicotine has also been implicated in free radical generation in various types of rodent and human cells, with a direct relationship between reactive oxygen species (ROS) induction and DNA damage (Yildiz et al., 1999; Argentin and Cichetti, 2004; Da Silva et al., 2010).

Another chemical group present in tobacco leaves is coumarins. Gasparotto Jr et al. (2005) showed that coumarins have significant molluscicidal activity against Biomphalaria glabrata. Our results confirmed the presence of coumarins and we believe that this chemical group accounts for the toxicity in $H$. aspersa after $72 \mathrm{~h}$, when $50 \%$ of the snails exposed to tobacco leaves died (data not shown). Overall, coumarins are not genotoxic, and both negative and positive responses have been reported for these compounds in the Ames test, sister chromatid exchange (SCE), MN and chromosome aberration tests in mammalian cells (Lake, 1999).

Flavonoids are phenolic compounds that are widely distributed in all foods of plant origin. Several beneficial properties have been attributed to these compounds, including antioxidant, anti-inflammatory and anticarcinogenic effects (Da Silva et al., 2002; Galati and O'Brien, 2004; Nunes et al., 2011). Flavonoids can be potentially harmful since some are mutagenic in bacterial and mammalian test systems (MacGregor, 1986; Skibola and Smith, 2000; Da Silva et al., 2002). Nevertheless, the data on flavonoid genotoxicity are incomplete and misleading results have been obtained with respect to mutagenicity in tests using mammalian cells (Skibola and Smith, 2000).

Our phytochemical analysis revealed only traces of saponins in tobacco leaves. This chemical group has anti- genotoxic and anti-mutagenic (Scarpato et al., 1998), antitumoral (Lee et al., 1999) and anti-inflammatory (Navarro et al., 2001) activities, and probably did not increase the DNA damage observed in snails fed tobacco leaves.

PIXE analysis revealed different levels of inorganic elements in tobacco leaves when compared with lettuce leaves (Table 2). The levels of trace elements in lettuce were obtained in a previous study by our group. All of the inorganic elements detected were present in much higher levels in tobacco leaves than in lettuce leaves. This difference reflects the fact that the two plants are different species. Studies in humans and animals have demonstrated that a wide variety of metals act as mutagenic and carcinogenic agents (Leonard et al., 2004). In general, metal genotoxicity is caused by indirect mechanisms, a major one of which involves interference with cellular redox regulation and the induction of oxidative stress (ROS generation), which may cause oxidative DNA damage (Beyersmann and Hartwig, 2008).

When digestive gland proteins and enzymes were analyzed (Table 2), the cytochrome P450 and P420 activities were lower in snails fed tobacco leaves compared with the control group. This decrease probably reflected the fact that nicotine and flavonoids inhibit cytochrome P450 activity, as observed by Shao et al. (2009) and Galati and O'Brien (2004). Galati and O'Brien (2004) also demonstrated that flavonoids inhibit drug-metabolizing enzymes. In addition, $\mathrm{P} 450$ isoforms are responsive to induction and inhibition by xenobiotics, including plant constituents (Ioannides, 2002; Ueng and Chen, 2004). Thus, inhibition of cytochrome enzymes in $H$. aspersa fed tobacco leaves may indicate that these snails can accumulate genotoxic agents capable of causing DNA damage. As indicated by Kim et al. (2002), the inhibition of cytochrome activity may disturb endocrine systems and lead to adverse effects such as carcinogenicity, immunological dysfunction and reproductive abnormality.

In conclusion, our results demonstrate that tobacco leaves are genotoxic in $H$. aspersa. The genotoxicity, mutagenicity and enzymatic inhibition caused by exposure to tobacco leaves was probably mediated by the complex mixture of substances (nicotine, coumarins, traces of saponins, flavonoids and different inorganic elements) present in these leaves. Our findings confirm the sensitivity of the Comet assay and MN test in detecting damage caused by 
complex mixtures such as that present in tobacco leaves. Several biological markers have been proposed for assessing exposure to tobacco or tobacco smoke in order to elucidate the mechanisms of DNA damage. In this work, we attempted to interpret the biological action of complex mixtures of components present in tobacco leaves. This approach may be useful for studying complex mixtures in other plant species.

\section{Acknowledgments}

The authors thank the farmer who granted us permission to collect tobacco leaves on his farm. This work was supported by grants from the Coordenadoria de Aperfeiçoamento de Pessoal de Nível Superior (CAPES), Conselho Nacional de Desenvolvimento Científico e Tecnológico (CNPq) and Fundação de Amparo à Pesquisa do Estado do Rio Grande do Sul (FAPERGS).

\section{References}

Argentin G and Cichetti R (2004) Genotoxic and antiapoptotic effect of nicotine on human gingival fibroblasts. Toxicol Sci 79:75-81

Beeby A and Richmond L (2002) Evaluating Helix aspersa as a sentinel for mapping metal pollution. Ecol Indic 1:261-270.

Beyersmann D and Hartwig A (2008) Carcinogenic metal compounds: Recent insight into molecular and cellular mechanisms. Arch Toxicol 82:493-512.

Campbell JL, Hopman TL, Maxwell JA and Nejedly Z (2000) The Guelph PIXE software package III: Alternative proton database. Nucl Instr Meth Phys Res 170:193-204.

Da Silva F, Erdtmann B, Dalpiaz T, Nunes E, Rosa D, Porawski M, Bona S, Simon C, Allgayer M and Da Silva J (2010) Effects of dermal exposure to Nicotiana tabacum (Jean Nicot, 1560) leaves in mouse evaluated by multiple methods and tissues. J Agric Food Chem 58:9868-9874.

Da Silva J, Herrmann SM, Heuser V, Peres W, Marroni NP, Gonzalez-Gallego J and Erdtmann B (2002) Evaluation of the genotoxic effect of rutin and quercetin by comet assay and micronucleus test. Food Chem Toxicol 40:941-947.

Doolittle DJ, Winegar R and Lee CK (1995) The genotoxic potential of nicotine and its major metabolites. Mutat Res 344:95-102.

Fent K (2003) Ecotoxicological problems associated with contaminated sites. Toxicol Lett 141:353-365.

Galati G and O'Brien PJ (2004) Potential toxicity of flavonoids and other dietary phenolics: Significance for their chemopreventive and anticancer properties. Free Radic Biol Med 37:287-303.

Gasparotto Jr A, Brenzan MA, Piloto IC, Cortez DGA, Nakamura CV, Filho BP, Filho ER and Ferreira AG (2005) Phytochemical study and evaluation of the molluscicidal activity of Calophyllum brasiliense Camb (Clusiaceae). Quim Nova 28:575-578.

Harborne JB (1998) Phytochemical Methods, A Guide to Modern Techniques of Plant Analysis. Chapman \& Hall Co., London, $320 \mathrm{pp}$.

Heuser V, Da Silva J, Moriske H, Dias J, Yoneama ML and Freitas T (2002) Genotoxicity biomonitoring in regions ex- posed to vehicle emissions using the comet assay and the micronucleus test in native rodent Ctenomys minutus. Environ Mol Mutagen 40:227-235.

Ianistcki M, Dallarosa J, Sauer C, Teixeira CE and Da Silva J (2009) Genotoxic effect of polycyclic aromatic hydrocarbons in the metropolitan area of Porto Alegre, Brazil, evaluated by $H$. aspersa (Müller, 1774). Environ Pollut 157:2037-2042.

Ioannides C (2002). Pharmacokinetic interactions between herbal remedies and medicinal drugs. Xenobiotica 32:451-478.

Kim JS, Ahn T, Yim S and Yun CH (2002) Differential effect of copper (II) on the cytochrome p450 enzymes and NADPHcytochrome p450 reductase: Inhibition of cytochrome p450-catalyzed reactions by copper (II) ion. Biochemistry 41:9438-9447.

Kleinsasser NH, Sassen AW, Semmler MP, Harréus UA, Licht AK and Richter E (2005) The tobacco alkaloid nicotine demonstrates genotoxicity in human tonsillar tissue and lymphocytes. Toxicol Sci 86:309-317.

Lake BG (1999) Coumarin metabolism, toxicity and carcinogenicity: Relevance for human risk assessment. Food Chem Toxicol 37:423-453.

Lee SJ, Sung JH, Leeb SJ, Moon CK and Lee B (1999) Antitumor activity of a novel ginseng saponin metabolite in human pulmonary adenocarcinoma cells resistant to cisplatin. Cancer Lett 144:39-43.

Leffa DD, Damiani AP, Da Silva J, Zocche JJ, dos Santos CE, Boufleur LA, Dias JF and De Andrade VM (2010) Evaluation of the genotoxic potential of the mineral coal tailings through the Helix aspersa (Müller, 1774). Arch Environ Contam Toxicol 59:614-621.

Leonard S, Bower J and Shi X (2004) Metal-induced toxicity, carcinogenesis, mechanisms and cellular responses. Mol Cell Biochem 255:3-10.

Lowry OH, Rosebrough NJ, Farr AL and Randall RJ (1951) Protein measurement with the Folin phenol reagent. J Biol Chem 193:265-275.

MacGregor JT (1986) Mutagenic and carcinogenic effects of flavonoids. In: Cody V, Middlenton E and Harbone JB (eds) Plant Flavonoids in Biology and Medicine, Biochemical Pharmacological and Structure-Activity Relationships. John Wiley \& Sons Inc., New York, pp 411-424.

Munzner R and Renner HW (1989) Genotoxic investigations of tobacco protein using microbial and mammalian test systems. Z Ernährungswiss 28:300-309.

Navarro P, Giner RM, Recio MC, Máñez S, Cerdá-Nicolás M and Rios JL (2001) In vivo anti-inflammatory activity of saponins from Bupleurum rotundifolium. Life Sci 68:1199-1206.

Nunes R, Kahl V, Sarmento M, Richter M, Costa-Lotufo L, Abin-Carriquiry J, Martinez M, Ferronatto S, Ferraz A and Da Silva J (2011) Antioxidant and antigenotoxicity activity of acerola fruit (Malpighia glabra l.) at two stages of ripeness. Plant Foods Hum Nutr 66:129-135.

Omura T and Sato R (1964) The carbon monoxide-binding pigment of liver microsomes. II - Solubilization, purification and properties. J Biol Chem 239:2379-2385.

Onuki M, Yokoyama K, Kimura K, Sato H, Nordim RB, Naing L, Morita Y, Sakai T, Kobayashi Y and Araki S (2003) Assessment of urinary cotinine as a marker of nicotine absorption from tobacco leaves: A study on tobacco farmers in Malaysia. J Occup Health 45:140-145. 
Parikh JR, Gokani VN, Kulkani PK, Shah AR and Saiyed HN (2005) Acute and chronic health effects due to green tobacco exposure in agricultural workers. Am J Ind Med 47:494499.

Pereira B, Rosa R, Da Silva J, Guecheva T, Oliveira I, Ianistcki M, Benvegnú V, Furtado G, Ferraz A, Richter M, et al. (2009) Protective effects of three extracts from Antarctic plants against ultraviolet radiation in several biological models. J Photochem Photobiol 96:117-129.

Sassen AW, Richter E, Semmler M, Harréus U, Gamarra F and Kleinsasser NH (2005) Genotoxicity of nicotine in miniorgan cultures of human upper aerodigestive tract epithelia. Toxicol Sci 88:134-141.

Scarpato R, Bertoli A, Naccarati A, Migliore L, Cocchi L, Barale R and Pistelli L (1998) Different effects of newly isolated saponins on the mutagenicity and cytotoxicity of the anticancer drugs mitomycin $\mathrm{C}$ and bleomycin in human lymphocytes. Mutat Res 420:49-54.

Shao T, Yuan H, Yan B, Lu Z and Min H (2009) Antioxidant enzyme activity in bacterial resistance to nicotine toxicity by reactive oxygen species. Arch Environ Contam Toxicol 57:456-462.

Singh NP, McCoy MT, Tice RR and Schneider E (1998) A simple technique for quantification of low levels of DNA damage in individual cells. Exp Cell Res 175:184-191.

Skibola CF and Smith MT (2000) Potential health impacts of excessive flavonoid intake. Free Radic Biol Med 29:375-383.

Snyman R, Reinecke S and Reinecke A (2000) Hemocytic lysosome response in the snail Helix aspersa after exposure to the fungicide copper oxychloride. Arch Environ Contam Toxicol 39:480-485.

Tambwekar KR, Kakariya RB and Garg S (2003) A validated high performance liquid chromatographic method for analysis of nicotine in pure form and from formulations. J Pharm Biomed Anal 32:441-450.

Trivedi A, Dave B and Adhvaryu S (1990) Assessment of genotoxicity of nicotine employing in vitro mammalian test systems. Cancer Lett 54:89-94.
Ueng Y and Chen R (2004) The role of cytochrome P450 in herb-drug interaction. Curr Pharmacogenom 2:209-218.

Villela I, Oliveira I, Silveira J, Dias J, Henriques J and Da Silva J (2007) Assessment of environmental stress by the micronucleus and comet assays on Limnoperna fortunei exposed to Guaíba hydrographic region samples (Brazil) under laboratory conditions. Mutat Res 628:76-86.

Vrolijk N, Targett N, Woodin B and Stegeman J (1994) Toxicological and ecological implication of biotransformation enzymes in tropical teleost Chaetodon capistratus. Marine Biol 119:151-158.

Wagner H and Bladt S (1996) Plant Drug Analysis: A Thin Layer Chromatography Atlas. Springer Verlag, Berlin, 369 pp.

Yildiz D, Liu Y, Ercal N and Armstrong D (1999) Comparison of pure nicotine and smokeless tobacco extract-induced toxicities and oxidative stress. Arch Environ Contam Toxicol 37:434-439.

\section{Internet Resources}

AFUBRA Associação dos Fumicultores do Brasil (2012) Fumicultura no Brasil, http://www.afubra.com.br (accessed May 15, 2012).

Hinds J (2012) The use of tobacco. Cumberland Presbyterian Publishing House. http://medicolegal.tripod.com/hinds 1882.htm (accessed May 23, 2012).

IPCS-INCHEM International Programme on Chemical Safety (2012). Nicotine. http://www.inchem.org/documents/pims/chemical/nicotine.htm (accessed May 22, 2012).

NIOSH Agricultural Health \& Safety Center News (2012) Southeast Center Studies Ways to Prevent Green Tobacco Sickness. http://www.cdc.gov/niosh/nora/symp06/pdfs/NORASymp osium2006Book.pdf (accessed December 5, 2012).

Associate Editor: Daisy Maria Fávero Salvadori

License information: This is an open-access article distributed under the terms of the Creative Commons Attribution License, which permits unrestricted use, distribution, and reproduction in any medium, provided the original work is properly cited. 